\title{
Possible ameliorative effect of nano- chocolate fortified with zinc on the hepatic and testicular toxicity induced by cadmium on male Swiss albino mice: histopathological and histomorphometrical studies
}

\author{
Sherin Ramadan Hamad(D)
}

\begin{abstract}
Background: Cadmium, as industrial pollutants considered as one of the most toxic environmental and most harmful heavy metals, was able to induce severe injury in several tissues.

Results: Intraperitoneal injection of cadmium (1.5 mg/kg bw) induced histopathological alterations in the architecture of both hepatic and testicular tissues as revealed by light microscope. It also induced histomorphometrical changes in the hepatic tissues, represented by a highly significant decrease in the area of hepatocyte; in the nucleus and ratio of nuclear/cytoplasm with a highly significant increase in the area of central vein; and in the testicular tissues with a highly significant decrease in the numbers of Leydig cells, height of germinal epithelium, and diameter of seminiferous tubule. Orally administrated of nano-chocolate fortified with zinc $(200 \mathrm{mg} / \mathrm{kg}$ ) resulted in marked improvement of the histopathological alterations and histomorphometrical changes induced by injection of cadmium in both the hepatic and the testicular tissues.
\end{abstract}

Conclusion: Oral administration of nano-chocolate fortified with zinc could suppress the toxicity of cadmium and combat tissue injury.

Keywords: Cadmium, Chocolate zinc nanoparticles, Histomorphometrical, Histopathological, Hepatic, Testicular

\section{Background}

Cadmium is widely spread in the environment and is considered the most toxic environmental and industrial pollutant. It is located in air, water, and nourishment (Joshi \& Bose, 2002; Krichah et al., 2003; Tongliang, Yuling, Weidong, \& Caiqiao, 2011) and is entered into soil and drinking water through agricultural and industrial activities. Cadmium also has highly soluble nature, so plants easily absorb and store it in crops for food and feed production (Sarwar et al., 2010). Therefore, it is recorded as the most harmful heavy metal to humans and aquatic organisms (Cinar, 2003; Kaplan, Yildirim, Yildirim, \& Cimen, 2011).

Correspondence: manaa_82@yahoo.com

Histopathological Department, National Organization for Drug Control and Research (NODCAR), Dokki, Giza, Egypt
Cadmium that is released into the air from hazardous waste sites or factories has resulted in impaired health, diarrhea, pain in stomach, lung damage, and infertility as well as fracture of bone (Singh, Chaudhary, Patni, \& Sankhla, 2007). The correlation between cadmium and cancer induction was proved by many studies (Flora \& Pachauri, 2010; Joseph, 2009). Rats treated with cadmium at dose $3 \mathrm{mg} / \mathrm{kg}$ bw revealed severe histopathological alterations in the liver, kidney, lung, and testicular tissues with chromosomal aberrations (El-Refaiy \& Eissa, 2013). In addition, Ibrahim et al. (2018) stated that cadmium administration resulted in hepatic and renal damage as detected by histopathological investigations.

From many years, natural products have been used in medicine as pharmaceuticals (Lu, Williams, \& Wang, 
2009; Manly, Padmanabha, \& Lowe, 2002). These compounds are potential therapeutic agents against many diseases such as cancer, microbial infection, and inflammation. But, their low bioavailabilities make them less successful in clinical trials. Therefore, the therapeutic effect of natural products would be increased when used in nanoparticles form into its delivery system (Watkins, Wu, Zhang, Davis, \& Xu, 2015). Nanomaterial is a particle of size ranging between 1 and $100 \mathrm{~nm}$ as recorded by many studies (Auffan et al., 2009).

In vitro and in vivo studies show that the bioavailability of natural products could be increased in nanoparticle forms. Also, materials in nanoparticles form have high capability to manipulate particles in order to target specific areas of the body and control the release of drugs (Watkins et al., 2015).

Recently, chocolate is considered as one of the most popular food types and flavors in the world (Katz, Doughty, \& Ali, 2011). A solid chocolate consists of cocoa mass, sugar, additives, cocoa butter, lecithin, and flavonoids (Richter \& Lannes, 2007). Cocoa (cacao) is the dried and fully fermented fatty seed of the fruit of the cocoa tree (Katz et al., 2011) and is represented $25 \%$ from the weight of any types of chocolate. It also contains high value of three types of flavonoids: procyanidins, catechins, and epicatechins (Arts, Hollman, \& Kromhout, 1999; Wollgast \& Anklam, 2000).

Flavonoids in chocolate have antimutagenic and antiproliferative effects on tumor cells through their antioxidant activity (Carnesecchi et al., 2002; Maskarinec, 2009; Weisburger, 2001). Many clinical studies reported that flavonoids in cocoa have a beneficial effect in preventing cardiovascular diseases (Corti, Flammer, Hollenberg, \& Luscher, 2009). When a male waster consumed milk and semisweet, dark, and soy chocolate, the phenolic content and antioxidant activity are increased in the cerebral cortex, hippocampus, and cerebellum (Medeiros, Koslowsky, Farias, Funchal, \& Dani, 2015). Similarly, consumption of chocolate under emotional stress induced positive effects on mood (Nehlig, 2013).

A number of cellular processes, such as cell proliferation, reproduction, immune function, and defense against free radicals, needed zinc as trace intracellular element (Powell, 2000). Zinc is considered as the most important nutritional factor influencing the metabolism and the toxicity of heavy metals, such as cadmium, and is protecting cellular components from oxidation. It plays an important role as an antioxidant, and its deficiency can induce free radical and can increase oxidative damage (Bruno et al., 2007). So, the present study aimed to evaluate the role of chocolate fortified with zinc nanoparticles in modulating hepatic and testicular toxicity induced by cadmium.

\section{Methods \\ Experimental design}

After a 1-week acclimatization period, the experimental animals were randomly divided into four groups, ten animals in each group as described in Table 1. The selected dose of cadmium was chosen according to Paniagua-Castro, Escalona-Cardoso, Hernández-Navarro, Pérez-Pastén, and Chamorro-Cevallos, (2011), while nano-chocolate fortified with zinc was chosen according to the result of acute toxicity test, which estimated that safe dose of chocolate nanoparticles was lower than or equal to $4000 \mathrm{mg} / \mathrm{kg}$.

The animals were sacrificed $24 \mathrm{~h}$ after cadmium administration, and both liver and testis tissues of all animals were collected for histopathological and histomorphometrical examinations.

Table 1 The experimental design of the experimental

\begin{tabular}{|c|c|c|c|c|}
\hline \multirow[t]{3}{*}{ Group } & \multirow{3}{*}{$\begin{array}{l}\text { Control } \\
1\end{array}$} & \multicolumn{3}{|l|}{ Experimental groups } \\
\hline & & \multirow{2}{*}{$\begin{array}{l}\text { Cadmium alone } \\
\text { - } 2 \text { (cadmium-treated } \\
\text { group) }\end{array}$} & \multirow{2}{*}{$\begin{array}{l}\text { Nano-Chocolate fortified with } \\
\text { zinc nanoparticle } \\
3 \text { (choco-treated group) }\end{array}$} & \multirow{2}{*}{$\begin{array}{l}\text { Cadmium-Nano-chocolate fortified with zinc } \\
\text { nanoparticle } \\
4 \text { (cadmium-choco-treated group) }\end{array}$} \\
\hline & & & & \\
\hline Sample size & 10 mice & 10 mice & 10 mice & 10 mice \\
\hline Distilled water & $\begin{array}{l}1 / 5 \mathrm{ml} \text {, } \\
\text { once }\end{array}$ & & & \\
\hline Cadmium & & $1.5 \mathrm{mg} / \mathrm{kg}$ & & $1.5 \mathrm{mg} / \mathrm{kg}$ \\
\hline $\begin{array}{l}\text { Nano-Chocolate fortified } \\
\text { with zinc }\end{array}$ & & & $200 \mathrm{mg} / \mathrm{kg}$ & $200 \mathrm{mg} / \mathrm{kg}$ \\
\hline Route & & i.p. & Oral & i.p. for cadmium; oral for chocolate \\
\hline Frequency & Single & Single & Single & Single \\
\hline Sampling time & 1 day & 1 day & 1 day & 1 day \\
\hline
\end{tabular}

i.p intraperitoneally 


\section{Materials}

Chemicals

Cadmium was purchased from Sigma-Aldrich Company (USA) and was dissolved in distilled water to prepare the used dose $(1.5 \mathrm{mg} / \mathrm{kg}$ bw) that was freshly prepared before use according to Paniagua-Castro et al. (2011).

Nano-chocolate fortified with zinc was manufactured by nanotechnology and purchased in the form of powder (100 g) from Lemako Misr Company, 10th of Ramadan City, Egypt. It was dissolved in sterile deionized water to freshly prepare the desired dose $(200 \mathrm{mg} / \mathrm{kg} \mathrm{bw}$, once), according to acute toxicity test of the study which estimated that safe dose of chocolate fortified with zinc was lower than or equal to $4000 \mathrm{mg} / \mathrm{kg}$.

The particle shape and size were estimated by transmission electron microscope (TEM).TEM measurements were performed by dissolving a drop of colloid solution from specimen onto a 400 mesh copper grid coated with an amorphous carbon film. Then, the solvent was evaporated in air at room temperature. The average diameter of the chocolate fortified with zinc nanoparticles was determined from the diameter of 100 nanoparticles found in several arbitrarily chosen areas in enlarged microphotographs.

\section{Model of animals}

Forty male Swiss albino mice were used in this study which weighted 25-30 g and aged 9-12 weeks. Experimental animals were obtained from animal house of $\mathrm{Na}$ tional Organization for Drug Control and Research (NODCAR), Egypt. They were acclimatized under house conditions (12-h lighting cycle and $25 \pm 2{ }^{\circ} \mathrm{C}$ temperatures) and were provided with free access to standard rodent chow and water.

All male Swiss albino mice were grouped and housed according to the guidelines of the institutional animal ethics committee of National Organization for Drug Control and Research (NODCAR). In addition, all experimental procedures were conducted in accordance with the ethical standards and were approved by the Institutional Animal Care and Use Committee (IACUC) at National Organization for Drug Control and Research (NODCAR), Giza, Egypt.

\section{Experimental procedures}

\section{Acute toxicity test for chocolate nanoparticles}

Safe dose for nano-chocolate fortified with zinc was calculated by acute toxic test. At the five dose levels, nano-chocolate fortified with zinc was administrated orally once into experimental animals, at doses $5000 \mathrm{mg} /$ $\mathrm{kg}$ bw, $4000 \mathrm{mg} / \mathrm{kg}$ bw, $3000 \mathrm{mg} / \mathrm{kg}$ bw, $2000 \mathrm{mg} / \mathrm{kg}$ bw, and $1000 \mathrm{mg} / \mathrm{kg}$ bw Then, the mortality, body weight, and clinical signs of animals were observed after $72 \mathrm{~h}$ of administration (Warheit et al., 2007). The safe dose was found to be $\leq 4000 \mathrm{mg} / \mathrm{kg}$ body weight.

\section{Histopathological and histomorphometrical examinations}

Liver and testis organs were preserved in $10 \%$ formaldehyde fixative for $48 \mathrm{~h}$, washed, dehydrated in ascending grades of alcohol, cleared in xylene and embedded in paraffin wax. Then, five micron thick paraffin sections were prepared, mounted on clean slides, and stained with Ehrlich's hematoxylin-eosin (Bancroft \& Gamble, 2002). Staining slides are examined under an Olympus microscope (BX41, Hamburg, Germany) and are photoed by Nikon camera for histopathological and histomorphometrical investigation.

\section{Histomorphometrical analysis in hepatic tissues}

The areas of the hepatocytes, nucleus of hepatocytes, and central veins were measured from randomly selected ten fields of liver sections stained with hematoxylin and eosin in all experimental groups (Bhadoria, Mahindra, Bahrioke, \& Bhadoria, 2015) using J-image program. These parameters were measured from 50 random hepatocytes and 50 random central veins from five slides. In addition, the ratio of the nucleus/cytoplasm was also recorded in control and treated group.

\section{Histomorphometrical analysis in testicular tissues}

Ten readings of Leydig cells were recorded in ten fields using an objective lens of magnification $\times 40$, i. e, of total magnification 400 (Gawish, Issa, Aziza, \& Ramadan, 2010). For measuring seminiferous tubule diameter, 90 round or nearly round cross-sections of seminiferous tubules were randomly chosen in each animal. Two perpendicular diameters of each cross-section of seminiferous tubules were measured at a magnification of $\times 40$. Germinal epithelium height was measured in 4 , equidistance of each cross-section of the seminiferous tubules using J-image program (Gholami, Ansari-Lari, \& Khalili, 2015).

\section{Statistical analysis}

Values were expressed as means \pm standard deviation (SD) for five samples for each group. $P$ value $\geq 0.05$ was considered as statistically significant, while $P$ values $\geq 0.001$ were considered as highly significant. All statistics were carried out using the analysis of variance (ANOVA) and GraphPad Prism software 5.01 (La Jolla, CA, USA) to determine differences between group means and standards errors.

\section{Results}

\section{Characterization of chocolate fortified with zinc nanoparticles}

TEM image analysis has shown that the nano-chocolate fortified with zinc is spherical in shape and the average size is within the range of $32-65 \mathrm{~nm}$ in diameter. All nanoparticles have a rough surface and definite spherical shape (Fig. 1). 

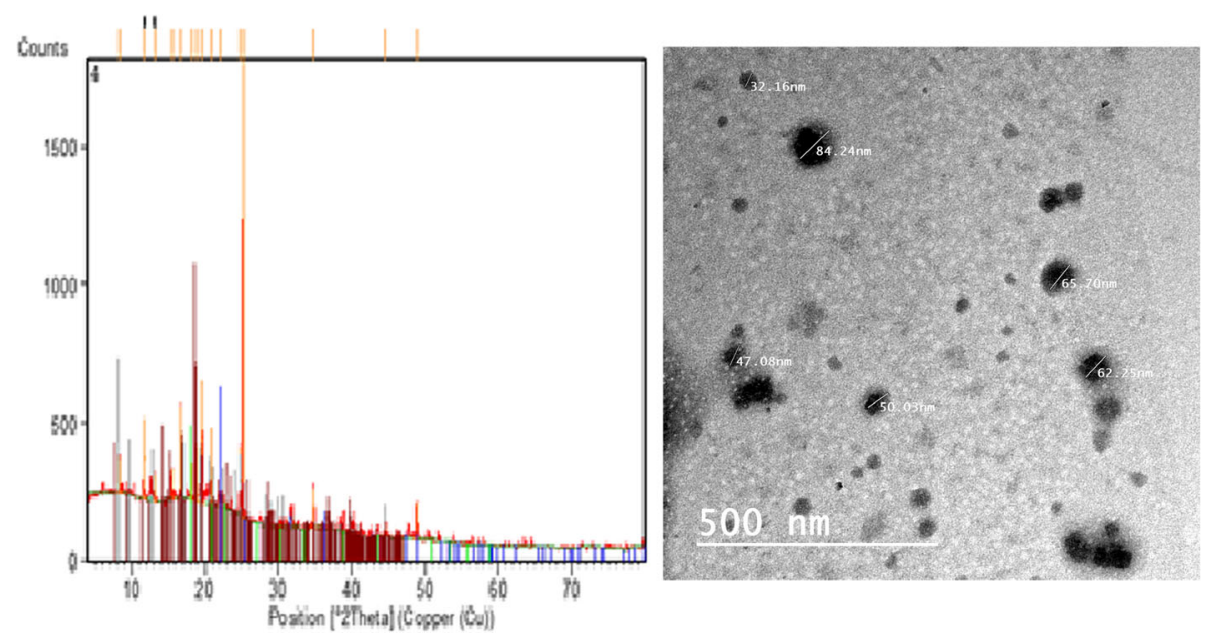

Fig. 1 Transmission electron microscopy (TEM) image of nano-chocolate fortified with zinc

\section{Hepatic tissues}

\section{Histopathological examination of hepatic tissues}

Histopathological studies of hepatic sections from normal animals showed normal hepatic architecture. Hepatic tissues consisted of hepatic lobules, which consisted from cords of hepatic cells (hepatocyte) and radiated from the central vein to periphery of the lobule. Also, narrow blood sinusoids separated the cell of cords and are lined by both Kupffer cells and endothelial cells (Fig. 2a). In contrast, hepatic sections from male mice treated with cadmium only showed hepatocyte with fatty change, scattered marked congested central vein, dilated congested portal vein, and proliferated bile duct compared to control-treated group (Fig. 2 b1). Prominent areas of dense aggregation of inflammatory cells, few enucleated hepatocytes, and hepatocyte with pyknotic nucleus and vacuolated cytoplasm were also noticed. Scattered necrotic areas, hemorrhage, and edema were also seen in some areas (Fig. 2b2 and b3).

Microscopical examination of hepatic sections from animals treated only with nano-chocolate fortified with zinc revealed no histological changes and hepatic sections from animals treated with cadmium and nano-chocolate fortified with zinc treatment revealed amelioration in the histological lesions induced by cadmium alone. Nano-chocolate fortified with zinc restored the normal appearance of hepatocytes, central vein, and sinusoids compared to cadmium-treated group (Fig. 2d).

\section{Histomorphometrical analysis of hepatic tissues}

Table 2 and Fig. 3 showed a highly significant decrease in the mean area of hepatocyte, nucleus, and nuclear/cytoplasm ratio together with a highly significant increase in the area of central vein in cadmium-treated animals compared to normal animals. Although, treatment with cadmium and nano-chocolate fortified with zinc nanoparticles resulted in a highly significant increase in the observed decrease in the mean size of hepatocyte and nucleus and nuclear/cytoplasm ratio and a highly significant decrease in the observed increase in the area of central vein induced by cadmium compared with control-treated group.

\section{Testicular tissues Histopathological examination of testicular tissues}

Sections of testis from control mice revealed the normal architecture of seminiferous tubules; each seminiferous tubule has complete spermatogenesis, and its lumen has sperms (Fig. 4a). However, most seminiferous tubules from male mice treated with cadmium only showed a marked reduction of spermatogenic layers, complete absence of sperms, and debris deposition in their lumen with hyaline degeneration. Widened interstitial areas with eosinophilia deposition, hemorrhage, congested blood vessels with thickened hyalinized wall, and disappearances of Leydig cells were observed in most areas compared to control-treated group (Fig. 4b1). Spermatocyte of others seminiferous tubules showed vacuolar nucleus or pyknotic nucleus (Fig. 4b2).

Histopathological examinations of sections of testis tissue from mice treated with nano-chocolate fortified with zinc nanoparticles only revealed normal structures of seminiferous tubules with normal appearance of spermatogenesis, sperms, and Leydig cells (Fig. 4c). Also, testis section of animals treated with cadmium and nano-chocolate fortified with zinc showed marked improvement in the histological structure of most seminiferous tubules and in the interstitial spaces with the reappearance of the Leydig cells compared to cadmium-treated group (Fig. 4d).

\section{Histomorphometrical analysis of testicular tissues}

Histomorphometrical studies of testicular tissues from male mice treated with cadmium $(1.5 \mathrm{mg} / \mathrm{kg}$, i.p. $)$ resulted in a highly significant decrease in the number of 

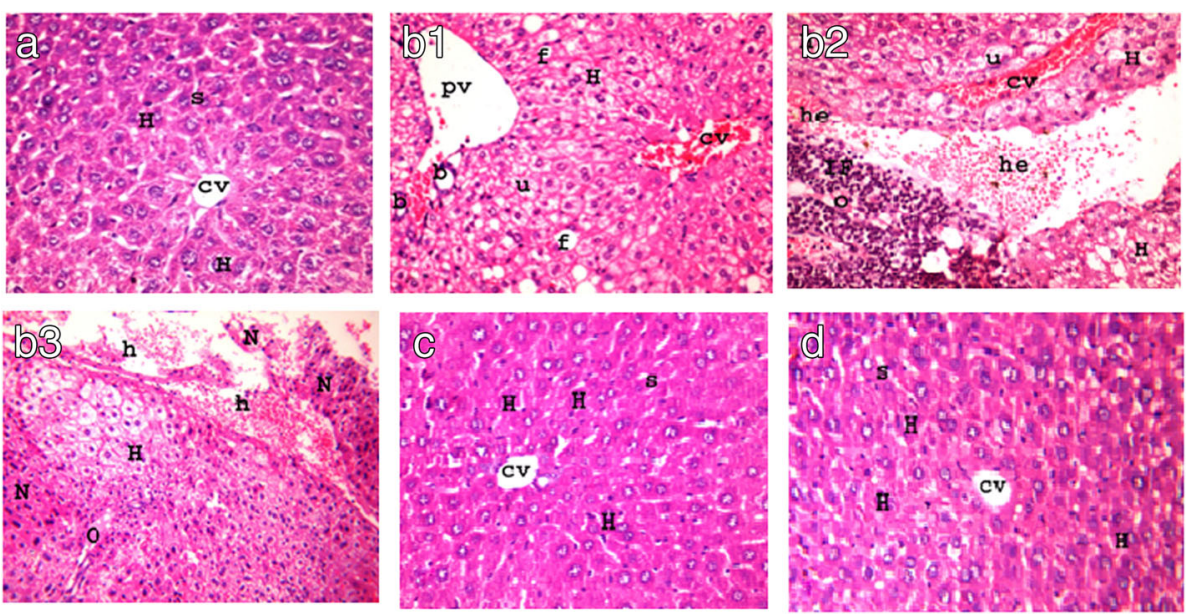

Fig. 2 A photomicrograph of liver sections. a Control group showing normal hepatic architectures with polygonal hepatocyte (H), normal central vein (CV), and sinusoid (S). b1 Mice treated with cadmium only showing scattered areas of fatty change $(f)$ in most hepatocyte and diffused extensive congested central vein (CV) with dilated congested portal vein (pv), and proliferated bile duct (b). b2 Mice treated with cadmium only showing severe dilated congested central vein (cv), few enucleated hepatocyte (u), scattered dense aggregation of inflammatory cells (IF), and hemorrhage (he). Hepatocyte with pyknotic nucleus and severe vacuolated cytoplasm $(H)$ together with edema (o) were also seen. b3 Mice treated with cadmium only showing scattered necrotic areas $(\mathrm{N})$, severe dilated congested central vein (cv), and hemorrhage (h). Hepatocyte with pyknotic nucleus and severe vacuolated cytoplasm $(\mathrm{H})$ together with edema (o) were also seen. c Mice treated with nano-chocolate fortified with zinc only showing hepatocyte with vesicular nucleolus $(\mathrm{H})$ and normal appearance of both central vein $(\mathrm{CV})$ and sinusoid (s). d Mice treated with cadmium and nano-chocolate fortified with zinc showing normal histological structure : normal shape of hepatocyte $(\mathrm{H})$ radiated in columns from central vein $(\mathrm{CV})$ and separated by sinusoid (s) (H \& EX 200)

Leydig cells, diameter of seminiferous tubule, and height of germinal epithelium in seminiferous tubule compared to the control-treated group. Administration of nano-chocolate fortified with zinc and cadmium resulted in modulation the toxicity of cadmium. Increase in the reduction of a number of the Leydig cells, seminiferous tubule diameter, and germinal epithelium height induced by cadmium to normal appearance compared with cadmium-treated group was also noticed (Table 3 and Fig. 5).

\section{Discussion}

Cadmium has a great degree of harmful effect to people (Jomova \& Valko, 2011; Nasiadek, Skrzypińska-Gawrysiak, Daragó, Zwierzyńska, \& Kilanowicz, 2014) and has high mobility (Brozska, Borowska, \& Tomczyk, 2016;
Kah, Levy, \& Brown, 2012. People are exposed to cadmium through drinking water, food, cigarette smoke, beverages, welding, ambient air (Chargui et al., 2011; Jarup \& Akesson, 2009; Tripathi \& Srivastav, 2011), mining, and manufacturing of batteries and pigments. Industrial activities, such as smelting and refining of metals, and municipal waste incineration also release cadmium into the atmosphere (Siu, Mruk, Porto, \& Cheng, 2009). Therefore, the aim of the present work was to evaluate the hepatic and testicular ameliorative effect of nano-chocolate fortified with zinc cadmium against the toxicity of cadmium in Swiss albino mice, using histopathological examination and histomorphometrical analysis.

In this work, the histopathological examination of the hepatic tissues in animals treated with cadmium

Table 2 Hepatic image analyses in male Swiss albino mice exposed to a sublethal concentration of cadmium individually and in mixture with nano-chocolate fortified with zinc

\begin{tabular}{lllll}
\hline $\begin{array}{l}\text { Parameters } \\
\text { Groups }\end{array}$ & $\begin{array}{l}\text { Area of } \\
\text { hepatocyte }\left(\mu m^{2}\right) \\
(\text { mean } \pm \text { SD) }\end{array}$ & $\begin{array}{l}\text { Area of } \\
\text { nucleus }\left(\mu m^{2}\right) \\
(m e a n \pm S D)\end{array}$ & $\begin{array}{l}\text { Nuclear/cytoplasm } \\
\text { ratio (\%) } \\
(\text { mean } \pm S D)\end{array}$ & $\begin{array}{l}\text { Area of central } \\
\text { veins }\left(\mu m^{2}\right) \\
(m e a n \pm S D)\end{array}$ \\
\hline Control-treated group & $49.85 \pm 4.533^{a}$ & $10.61 \pm 2.097^{a}$ & $25.28 \pm 3.47^{a}$ & $92.18 \pm 12.45^{a}$ \\
Cadmium-treated group & $22.924 \pm 1.6^{b^{b^{* *}}}$ & $2.88 \pm 0.613^{b^{* *}}$ & $15.75 \pm 2.56^{b^{* *}}$ & $346.07 \pm 49.07^{b^{* *}}$ \\
Choco-treated group & $47.11 \pm 4.584^{a^{* *}}$ & $9.27 \pm 1.043^{a^{* *}}$ & $24.83 \pm 1.81^{a^{* *}}$ & $95.92 \pm 12.49^{a^{* *}}$ \\
Cadmium-choco-treated group & $48.59 \pm 4.219^{\mathrm{a}^{* *}}$ & $11.11 \pm 1.51^{\mathrm{a}^{* *}}$ & $27.89 \pm 2.88^{\mathrm{a}^{* *}}$ & $98.42 \pm 17.27^{\mathrm{a}^{* *}}$ \\
\hline
\end{tabular}

Ten animals were used in each group. Data are represented as mean \pm SD

Means with the same letter are not significantly different.

${ }^{*} P<0.05$ is significant

${ }^{*} P<0.01$ is highly significant 

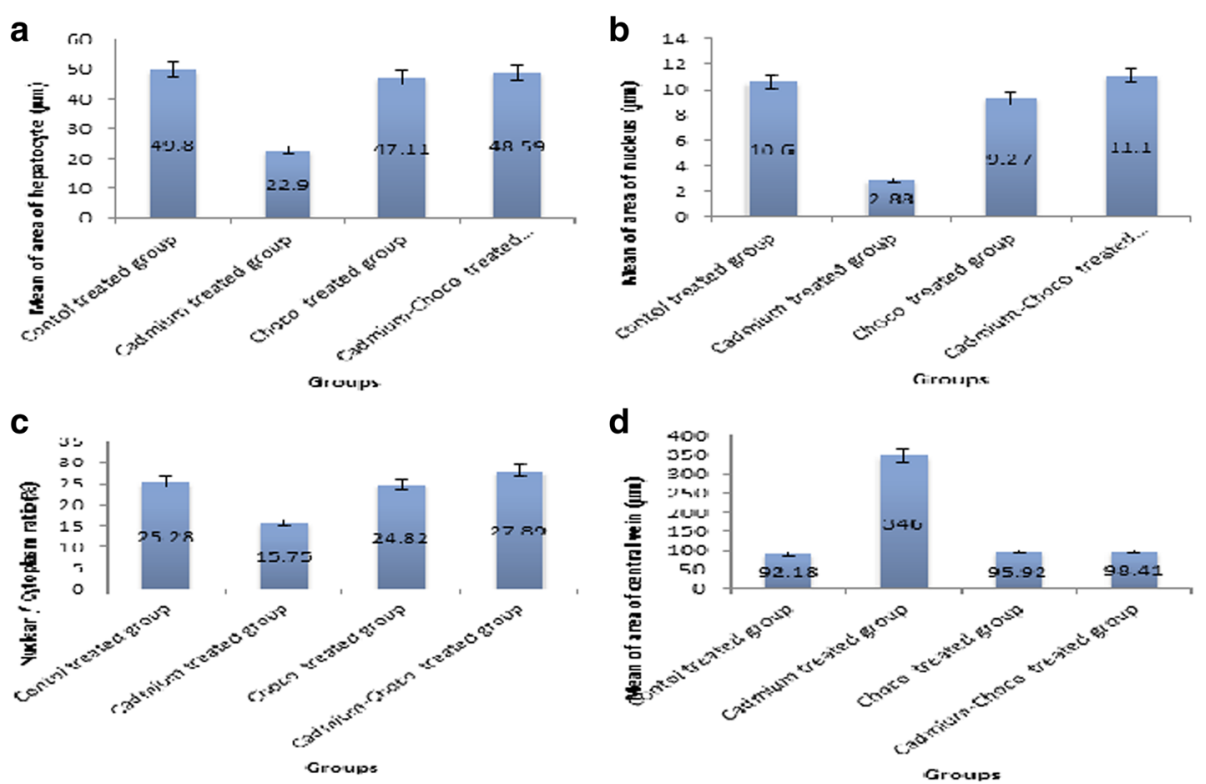

Fig. 3 Histomorphometrical analysis of hepatic tissues mice injected with nano-chocolate fortified with zinc and/or cadmium. a Area of hepatocyte $\left(\mu \mathrm{m}^{2}\right)$. b Area of nucleus $\left(\mu \mathrm{m}^{2}\right)$. c Nuclear/cytoplasm ratio. $\mathbf{d}$ Area of central vein $\left(\mu \mathrm{m}^{2}\right)$

revealed prominent areas of hepatocyte with pyknotic nucleus and vacuolated cytoplasm, severe congested central vein, scattered necrotic areas, and hemorrhage, and histomorphometrical analysis revealed a highly significant decrease in the area of hepatocyte $(22.924$ $\pm 1.6)$, nucleus (2.88 \pm 0.613$)$, and nuclear/cytoplasm ratio $(15.75 \pm 2.56)$ with a highly significant increase in the area of central vein $(346.07 \pm 49.07)$ compared to control treated group $(49.85 \pm 4.533,10.61 \pm 2.097$, $25.28 \pm 3.47$, and $92.18 \pm 12.45 ; P<0.05)$. Our results were confirmed by Gong et al., (2008) and Renugadevi and Prabu (2010). This study also revealed that treatment with cadmium resulted in obvious changes in testicular tissues such as a marked reduction of spermatogenic layers,

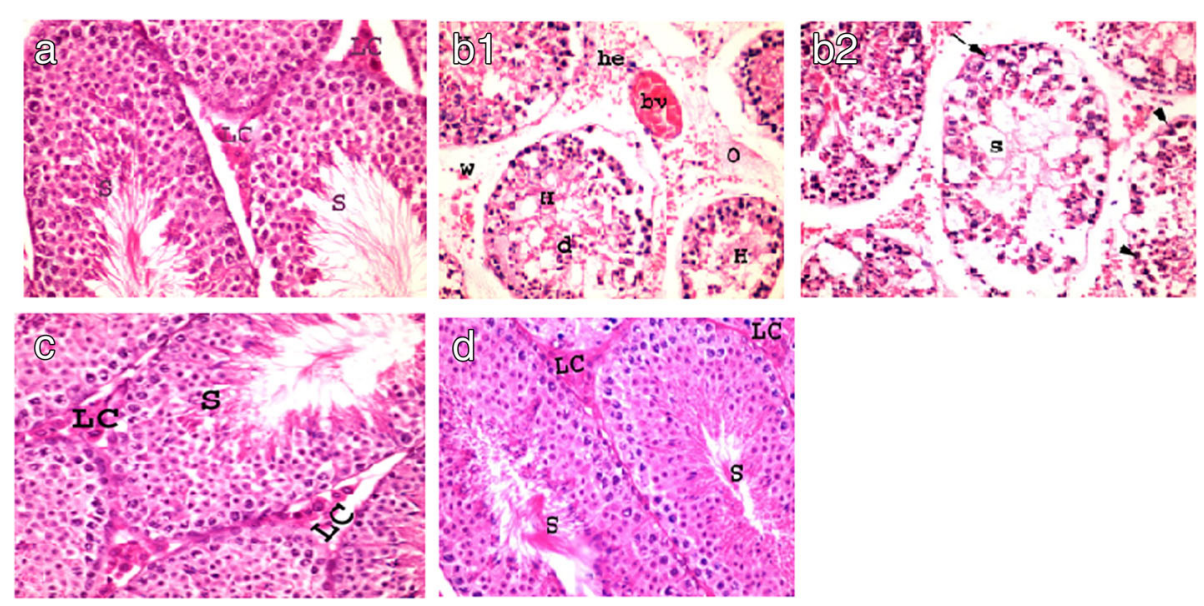

Fig. 4 A photomicrograph of testis sections. a Normal male Swiss albino mice showing normal histology of seminiferous tubules with complete spermatogenic layers (s). Leydig cells also showed normal appearance (LC). b1 Male Swiss albino mice treated with cadmium only showing seminiferous tubules with marked reduction of spermatogenic layers and absence of sperms (S), hyaline degeneration with esinophilic deposition, $(\mathrm{H})$ and debris deposition in their lumen. Widened intertubuler areas ( $\mathrm{W}$ ) showed congested blood vessels with thickened hyalinized wall (b.v), with eosinophilia deposition $(\mathrm{O})$, hemorrhage (he), and disappearances of Leydig cells ( $\mathrm{L}$ ). b2 Male Swiss albino mouse treated with cadmium only showing spermatocyte of seminiferous tubules with vacuolar nucleus (arrow) or pyknotic nucleus (arrow head). c Male Swiss albino mice treated with chocolate fortified with zinc nanoparticles showing normal seminiferous tubules with normal appearance of spermatogenesis, sperms, and Leydig cells. $\mathbf{d}$ Male Swiss albino mouse treated with cadmium and chocolate fortified with zinc nanoparticles showing normal histological structure of seminiferous tubules. Complete spermatogenesis and presence of sperm. Also, Leydig cells showed normal appearance (H \& E X 400) 
Table 3 Testicular morphometric analyses in male Swiss albino mice exposed to sublethal concentration of cadmium individually and in mixture with chocolate fortified with zinc nanoparticles

\begin{tabular}{llll}
\hline Parameters & $\begin{array}{l}\text { Number of } \\
\text { Geydig cells } \\
(\text { mean } \pm \text { SD) }\end{array}$ & $\begin{array}{l}\text { Diameter of seminiferous } \\
\text { tubule }(\mu \mathrm{m}) \\
(\text { mean } \pm S D)\end{array}$ & $\begin{array}{c}\text { Height of germinal epithelium } \\
\text { in seminiferous tubule }(\mu \mathrm{m}) \\
(\mathrm{mean} \pm \mathrm{SD})\end{array}$ \\
\hline Control-treated group & $10 \pm 2.121^{\mathrm{a}}$ & $2.697 \pm 0.531^{\mathrm{a}}$ & $0.748 \pm 0.107^{\mathrm{a}}$ \\
Cadmium-treated group & $0.8 \pm 0.374^{\mathrm{b}^{* *}}$ & $1.489 \pm 0.136^{\mathrm{b}^{* *}}$ & $0.371 \pm 0.027^{\mathrm{b}^{* *}}$ \\
Choco-treated group & $10.2 \pm 1.562^{\mathrm{a}^{* *}}$ & $2.559 \pm 0.437^{\mathrm{a}^{* *}}$ & $0.736 \pm 0.167^{\mathrm{a}^{* *}}$ \\
Cadmium-choco-treated group & $10.6 \pm 2.039^{\mathrm{a}^{* *}}$ & $2.709 \pm 1.163^{\mathrm{a}^{* *}}$ & $0.758 \pm 0.112^{\mathrm{a}^{* *}}$
\end{tabular}

Ten animals were used in each group. Data are represented as mean \pm SD

Means with the same letter are not significantly different.

${ }^{*} P<0.05$ is significant

${ }^{* *} P<0.01$ is highly significant

complete absence of sperms in most seminiferous tubules, widened interstitial areas, and disappearances of Leydig cells. A highly significant decrease in the number of Leydig cells $(0.8 \pm 0.374)$, diameter of seminiferous tubule $(1.489 \pm 0.136)$, and height of germinal epithelium in seminiferous tubule $(0.371 \pm 0.027)$ was also recorded compared to the control-treated group $(10 \pm 2.121 ; 2.697$ and $0.748 \pm 0.107 ; P<0.05)$; these were in agreement with the previous works of Burukoğ lu and Bayc u (2008); Fouad, Qureshi, Al-Sultan, Yacoubi, and Ali (2009); and Souza, Diamante, and Dolder (2010)). The results were also in agreement with other studies (El-Refaiy \& Eissa, 2013), who reported that when the rats were exposed to cadmium ( $3 \mathrm{mg} / \mathrm{kg} \mathrm{bw}$ ), severe histopathological changes in the liver, kidney, lung, and testicular tissues were recorded.

The observed hepatic and testicular toxicity of cadmium could be attributed to increase cadmium concentration in the tissues (Josthna, Geetharathan, Sujatha, \& Deepika, 2012). Previous studies reported that cadmium was accumulated in different tissues such as the lung, brain, testis, kidney, liver, blood system, and bone and caused severe damage to these tissues (Ercal, Gurer-Orhan, \& Aykin-Burns, 2001). The same was proved by many studies that reported the accumulation of cadmium in different tissues causing metabolic, histological, and pathological changes that lead to chronic illnesses in humans, such as kidney diseases, cancer, diabetes, neurological diseases, bone diseases, and cardiovascular diseases (Fagerberg, Bergstrom, Boren, \& Barregard, 2012; Li et al., 2016; Mates, Segura, Alonso, \& Marquez, 2010; Navas-acien et al., 2009; Peters, Perlstein, Perry, Mcneely, \& Weuve, 2010; Schwartz, Il'yasova, \& Ivanova, 2003; Waalkes, 2003). Depletion of antioxidant enzymes (as superoxide dismutase and catalase) and elevation of free radical species, oxidative stress, lipid peroxidation, and malondialdehyde could also be considered as another reason that explained the observed toxicity of cadmium (Babu, Rajmohan, Rajan, \& Kumar, 2006; Ibrahim et al., 2018; Moitra, Brashier, \& Sahu, 2014; Nemmiche, 2017; Renugadevi \& Prabu,
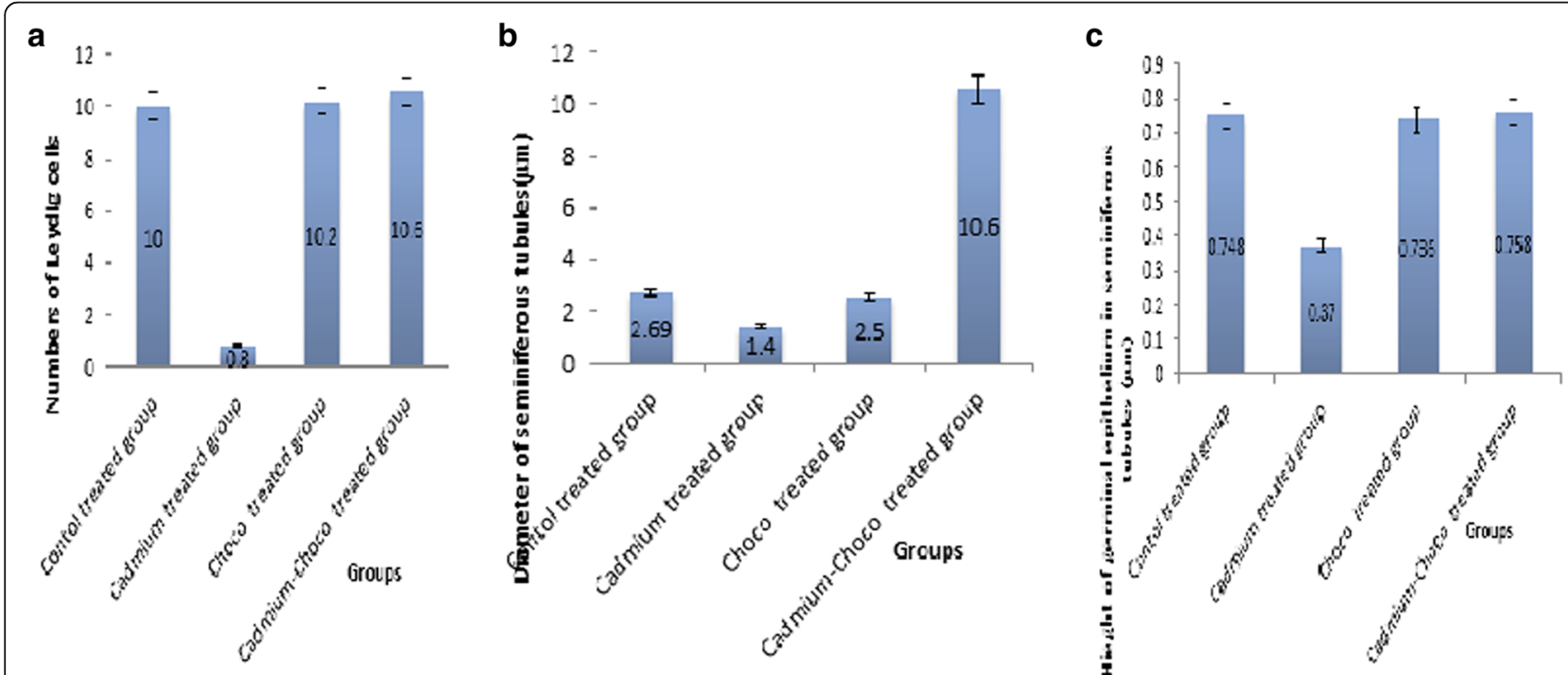

Fig. 5 Histomorphometrical analysis of testicular tissues from mice treated with cadmium and/or nano-chocolate fortified with zinc nanoparticles. a Number of Leydig cells. b Diameter of seminiferous tubule $(\mu \mathrm{m})$. $\mathbf{c}$ Height of germinal epithelium $(\mu \mathrm{m})$ 
2010; Vasiljeva, Berzina, \& Remeza, 2011; Vasiljeva, Smirnova, Basova, \& Babarykin, 2018). Cadmium induced oxidative damage to the cellular macromolecules and cellular structures (Curcic et al., 2014; Rahman et al., 2017).

On another hand, treatment with cadmium and nano-chocolate fortified with zinc improved histopathological lesions and morphometrical changes in the hepatic and testicular tissues induced by cadmium.

It restored area of hepatocyte $(48.59 \pm 4.219)$, nucleus (11.11 \pm 1.51$)$, nuclear/cytoplasm ratio $(27.89 \pm 2.88)$, and central vein $(98.42 \pm 17.27)$ to normal means $(49.85 \pm 4.533$, $10.61 \pm 2.097, \quad 25.28 \pm 3.47$, and $92.18 \pm 12.45 ; \quad P<0.05)$ compared to the cadmium-treated group $(22.924 \pm 1.6$, $2.88 \pm 0.613,15.75 \pm 2.56$, and $346.07 \pm 49.07$ ); these agreed with Aidoo et al. (2012). Decreases in the Leydig cell number (10.6 \pm 2.039$)$, seminiferous tubule diameter (2.709), and germinal epithelium height $(0.758 \pm 0.112)$ in seminiferous tubule induced by cadmium $(0.8 \pm 0.374$, $1.489 \pm 0.136$, and $0.371 \pm 0.027$ ) were abated by the nano-chocolate fortified with zinc compared to the control-treated group (10. $\pm 2.121 ; 2.697$ and $0.748 \pm 0.107$; $P<0.05)$. These observed modulation effects of nano-chocolate fortified with zinc could be attributed to the combination of several different mechanisms including antioxidant activity, anti-inflammatory properties, and direct scavenging of free radicals as recorded by Aidoo et al. (2012); Matović, Buha, Bulat, and Dukić-Ćosić (2011); Kostecka-Sochoń et al., (2018); Medeiros et al. (2015); Oteiza (2012); and Vinson et al. (2006).

When used, the chocolate in nanoparticle form enhanced its nutritional properties and improved its total phenolic content and antioxidant activity without remarkable changes in its fineness and melting profile properties (Rahadian, Saputro, Rottiers, de Walle, \& Dewettinck, 2018). Recently, a lot of research investigated nanoparticles for numerous medical applications. Nanoparticles are used as a potential delivery method for diagnostic and therapeutic agents and could be able to overcome certain biological and physical barriers where conventional therapies fail. Their particle size is typically between 100 and $300 \mathrm{~nm}$ (Hill \& Li, 2017) and has a high surface area; these allowed interested agent to bound to their surface, allowing for the delivery of therapeutics that would be otherwise unstable, insoluble, or biologically inactivated under typical conditions (Arsalani et al., 2012; Hultman et al., 2008; Neuwelt, Hamilton, Varallyay, et al., 2009).

Another reason for the beneficial effect of nano-chocolate fortified with zinc observed in the current study, due to antioxidant properties of zinc. Brzóska, Rogalska, and Kupraszewicz (2011) and Matović et al. (2011) reported that when zinc supply is increased in the tissues, the toxic effects of cadmium were reduced by zinc antagonistic activity towards toxic metal. Likewise, Brzóska, Rogalska, Galażyn-Sidorczuk, et al. (2007); Chasapis, Loutsidou, Spiliopoulou, and Stefanidou (2012); Jurczuk, Brzóska, Moniuszko-Jakoniuk, Gałażyn-Sidorczuk, and Kulikowska-Karpińska (2004); and Rogalska, Piłat-Marcinkiewicz, and Brzóska (2011) reported that zinc has antioxidant properties and efficient protection against many toxic effects of cadmium on the organism, including the damage of the kidneys, liver, and bones. Moreover, Kostecka-Sochoń and Dąbrowska, (2013), stated that zinc administration can increase activity of both glutathione peroxidase and catalase and can reduce the $\mathrm{H} 2 \mathrm{O} 2$ levels, this that confirming zinc's antioxidant effect.

Chocolate is widely consumed in the world and contains a high amount of phenolic compounds (Manach, Scalbert, Morand, Remesy, \& Jimenez, 2004; Medeiros et al., 2015). It consisted of cocoa liquor, cocoa butter, and sugar. Cocoa liquor has many bioactive compounds, and cocoa butter has fatty acids, while the nonfat cocoa solids have vitamins, minerals, fiber, and polyphenols (Katz et al., 2011). Similarly, Medeiros et al. (2015) stated that different types of chocolate have high phenolic content and antioxidant activity in vitro and in vivo. They also, reported that addition of chocolate in the diet of the rats reduced lipid peroxidation and protein oxidation caused by hydrogen peroxide and increase superoxide dismutase in the cerebral cortex, hippocampus, and cerebellum of male Wistar. Dani, Oliboni, Agostini, et al. (2010); Duarte-Almeida, Dos Santos, Genovese, and Lajolo (2006); and Spada, Souza, Dani, et al. (2009) reported also that phenolic compounds have antioxidant capacity and have the ability to delay the rate of oxidation by the inhibition of reactive oxygen species.

Cocoa has been used for centuries as a medicine to combat inflammation, pain, and numerous ailments (Dillinger et al., 2000). Moreover, the consumption of cocoa powder enhances the antioxidant capacity of plasma and decreases the content of lipid oxidation products in human and rat plasma (Baba, Osakabe, Natsume, et al., 2000). Cocoa has many polyphenolic compounds, especially flavonoids-specifically flavanols, also called flavan-3-ols (Buijsse, Weikert, Drogan, Bergmann, \& Boeing, 2010). It also contains methylxanthine compounds (theobromine), caffeine, as an antioxidant product (Katz et al., 2011).

Main flavanols in cocoa are epicatechin, catechin, and procyanidins (Katz et al., 2011). Ramiro-Puig and Castell (2009) recorded that procyanidins are responsible for the majority of antioxidant activity in cocoa products. They also reported that procyanidins prevent the growth of lung cancer cells of human in vitro and in vivo by inhibiting the prostaglandin E (2) and prostaglandin E (2) receptors. 


\section{Conclusion}

\section{Ameliorative effect of Nano-chocolate fortified with zinc} on the toxicity of cadmium was studied

The results of the current study showed that oral administration of nano-chocolate fortified with zinc ameliorated the hepatic histological lesions induced by cadmium alone and restored the normal appearance of hepatic structures. It also indicated the efficiency of nano-chocolate fortified with zinc to restore the original appearance of testicular tissue and to ameliorate the number of Leydig cells in male Swiss albino mice as indicated by histopathological and histomorphometrical examinations. The ameliorating effect of chocolate fortified with zinc nanoparticles against cadmium toxicity in hepatic and testicular tissues could be attributed to their antioxidant, anti-inflammatory, and scavenge free radicals properties.

\section{Acknowledgements}

The author $(\mathrm{SRH})$ thanks, greatly honors, and expresses deep gratitude to Dr. Hanan Ramadan Hamed, in Genetics, Zoology Department, Faculty of Science, Cairo University for helping and sharing in practical research.

\section{Funding}

The author has declared no funding for the research.

\section{Availability of data and materials}

The national organization for drug control and research provided some of materials and data.

\section{Authors' contributions}

S.R. Hamad has done all the working of the manuscript. The author read and approved the final manuscript.

\section{Ethics approval and consent to participate} Not applicable

\section{Consent for publication}

Not applicable

\section{Competing interests}

The author declares that he/she has no competing interests.

\section{Publisher's Note}

Springer Nature remains neutral with regard to jurisdictional claims in published maps and institutional affiliations.

Received: 3 December 2018 Accepted: 3 April 2019

Published online: 16 May 2019

\section{References}

Aidoo, E., Adda, F. K., Ahenkorah, J., Hottor, B., Bugyei, K. A., \& Gyan, B. A. (2012) Natural cocoa ingestion reduced liver damage in mice infected with plasmodium berghei (NK65). Research and Reports in Tropical Medicine, 3, 107-116.

Arsalani, N., Fattahi, H., Laurent, S., Burtea, C., Van der Elst, L., \& Muller, R. N. (2012). Polyglycerol-grafted superparamagnetic iron oxide nanoparticles: highly efficient MRI contrast agent for liver and kidney imaging and potential scaffold for cellular and molecular imaging. Contrast Media \& Molecular Imaging, 7(2), 185-194.

Arts, I. C. W., Hollman, P. C. H., \& Kromhout, D. (1999). Chocolate as a source of tea flavonoids. The Lancet., 354(9177), 488.

Auffan, M., Rose, J., Bottero, J. Y., Lowry, G. V., Jolivet, J. P., \& Wiesner, M. R. (2009). Towards a definition of inorganic nanoparticles from an environmental health and safety perspective. Nature Nanotechnology, 4(10), 634-641.
Baba, S., Osakabe, N., Natsume, M., et al. (2000). Cocoa powder enhances the level of antioxidative activity in rat plasma. The British Journal of Nutrition, 84(5), 673-680

Babu, K. R., Rajmohan, H. R., Rajan, B. K., \& Kumar, K. M. (2006). Plasma lipid peroxidation and erythrocyte antioxidant enzymes status in workers exposed to cadmium. Toxicology \& Industrial Health., 22, 329-335.

Bancroft, J., \& Gamble, M. (2002). Theory and practice of histological techniques. 5th (Ed.). London: Churchil Livingstone.

Bhadoria, P., Mahindra, N. M., Bahrioke, V., \& Bhadoria, A. S. (2015). Effect of ethephon on the liver in albino rats: a histomorphometric study. Biomedical Journal, 38(5), 421-427.

Brozska, M., Borowska, S., \& Tomczyk, M. (2016). Antioxidants as a potential preventive and therapeutic strategy for cadmium. Current Drug Targets., 17 1350-1384.

Bruno, R. S., Song, Y. Leonard, S. W.., Mustacich, D. J., Taylor, A. W. Traber, M. G., \& Ho, E. (2007). Dietary zinc restriction in rats alters antioxidant status and increases plasma F2-isoprostanes. The Journal of Nutritional Biochemistry., 18(8), 509-518.

Brzóska, M. M. Rogalska, J., Galażyn-Sidorczuk, M., et al. (2007). Effect of zinc supplementation on bone metabolism in male rats chronically exposed to cadmium. Toxicology, 237(1-3), 89-103.

Brzóska, M. M., Rogalska, J., \& Kupraszewicz, E. (2011). The involvement of oxidative stress in the mechanisms of damaging cadmium action in bone tissue. A study in a rat model of moderate and relatively high human exposure. Toxicology and Applied Pharmacology., 250(3), 327-335.

Buijsse, B., Weikert, C., Drogan, D., Bergmann, M., \& Boeing, H. (2010). Chocolate consumption in relation to blood pressure and risk of cardiovascular disease in German adults. European Heart Journal, 31, 1616-1623.

Burukoğ lu, D., \& Bayc u, C. (2008). Protective effects of zinc on testes of cadmium-treated rats. Bulletin of Environmental Contamination and Toxicology, 81, 521-524

Carnesecchi, S., Schneider, Y., Lazarus, S. A., Coehlo, D., Gosse, F., \& Raul, F. (2002). Flavanols and procyanidins of cocoa and chocolate inhibit growth and polyamine biosynthesis of human colonic cancer cells. Cancer Letters, 175(2), 147-155.

Chargui, A., Zekri, S., Jacquillet, G., Rubera, I., Ilie, M., Belaid, A., ... Mograbi, B. (2011). Cadmium-induced autophagy in rat kidney: An early biomarker of subtoxic exposure. Toxicological Sciences, 121, 31-42.

Chasapis, C. T., Loutsidou, A. C., Spiliopoulou, C. A., \& Stefanidou, M. E. (2012). Zinc and human health: An update. Archives of Toxicology, 86(4), 521-534.

Cinar, M. (2003). Cadmium and effects at biological system. Veterinarium, 14, 79-84.

Corti, R., Flammer, A. J., Hollenberg, N. K., \& Luscher, T. F. (2009). Cocoa and cardiovascular health. Circulation., 119(10), 1433-1441.

Curcic, M., Durgo, K., Kopjar, N., Ancic, M., Vucinic, S., \& Antonijevic, B. (2014). Cadmium and decabrominated diphenyl ether mixture: in vitro evaluation of cytotoxic, prooxidative and genotoxic effects. Environmental Toxicology and Pharmacology, 38(2), 663-671.

Dani, C., Oliboni, L. S., Agostini, F., et al. (2010). Phenolic content of grapevine leaves (Vitis labrusca var. Bordo) and its neuroprotective effect against peroxide damage. Toxicology in Vitro., 24(1), 148-153.

Dillinger, T. L., Barriga, P., Escarcega, S., Jimenez, M., Lowe, D. S., \& Grivetti, L. E. (2000). Food of the gods: cure for humanity? A cultural history of the medicinal and ritual use of chocolate. The Journal of Nutrition, 130 (8 Suppl) 2057-2072.

Duarte-Almeida, J. M., Dos Santos, R. J., Genovese, M. I., \& Lajolo, F. M. (2006). Evaluation of the antioxidant activity using the -carotene/linoleic acid system and the DPPH scavenging method. Ci'encia e Tecnologia de Alimentos., 26(2), 446-452.

El-Refaiy, A. I., \& Eissa, F. I. (2013). Histopathology and cytotoxicity as biomarkers in treated rats with cadmium and some therapeutic agents. Saudi Journal of Biological Sciences., 20, 265-280.

Ercal, N., Gurer-Orhan, H., \& Aykin-Burns, N. (2001). Toxic metals and oxidative stress. Part 1. Mechanisms involved in metal-induced oxidative damage. Current Topics in Medicinal Chemistry., 1(6), 529-539.

Fagerberg, B., Bergstrom, G., Boren, J., \& Barregard, L. (2012). Cadmium exposure is accompanied by increased prevalence and future growth of atherosclerotic plaques in 64-year-old women. Journal of Internal Medicine, 272, 601-610.

Flora, S. J. S., \& Pachauri, V. (2010). Chelation in metal intoxication. International Journal of Environmental Research and Public Health, 7, 2745-2788.

Fouad, A. A., Qureshi, H. A., Al-Sultan, A. I., Yacoubi, M. T., \& Ali, A. A. (2009). Protective effect of hemin against cadmiuminduced testicular damage in rats. Toxicology., 257, 153-160 
Gawish, A. M., Issa, A. M., Aziza, M. A., \& Ramadan, S. (2010). Morphometrical, histopathological, and cytogenetical ameliorating effects of green tea extract on nicotine toxicity of the testis of rats. Journal of American Science., 6(11), 401-411.

Gholami, S., Ansari-Lari, M., \& Khalili, L. (2015). Histologic and histomorphometric changes of testis following oral exposure to methyl tertiary-butyl ether in adult rat. Iranian Journal of Veterinary ResearchShiraz University.No. 3, Ser. No. $52,16,288-292$.

Gong, P., Chen, F. X., Ma, G. F., Feng, Y., Zhao, Q. Y., \& Wang, R. (2008). Endomorphin 1 effectively protects cadmium chlorideinduced hepatic damage in mice. Toxicology., 251, 35-44.

Hill, E. K., \& Li, J. (2017). Current and future prospects for nanotechnology in animal production. Journal of Animal Science and Biotechnology., 1-13.

Hultman, K. L., Raffo, A. J., Grzenda, A. L., Harris, P. E., Brown, T. R., \& O'Brien, S. (2008). Magnetic resonance imaging of major histocompatibility class II expression in the renal medulla using immunotargeted superparamagnetic iron oxide nanoparticles. ACS Nano, 2(3), 477-484 [PubMed].

Ibrahim, M. A.-B., Almaeen, A.-R. H., Abd El Moneim, M., Tammam, H. G., Athar Khalifa, M., \& Nasibe, M. N. (2018). Cadmium-induced hematological, renal, and hepatic toxicity: the amelioration by Spirulina platensis. The Saudi Journal of Forensic Medicine and Sciences., 1(1), 4-13.

Jarup, L., \& Akesson, A. (2009). Current status of cadmium as an environmental health problem. Toxicology and Applied Pharmacology, 238, 201-208.

Jomova, K., \& Valko, M. (2011). Advances in metal-induced oxidative stress and human disease. Toxicology, 283, 65-87.

Joseph, P. (2009). Mechanisms of cadmium carcinogenesis. Toxicology and Applied Pharmacology., 238, 272-279.

Joshi, P. K., \& Bose, M. (2002). Toxicity of cadmium: a comparative study in the air breathing fish, Clarias batrachus and in non-air breathing one, Ctenopharyngodon idellus. In C. Kennedy, A. Kolok, \& D. MacKinlay (Eds.), Aquatic toxicology: mechanism and consequences, (pp. 109-118). Ottawa: Int. Congress of Fish Biology.

Josthna, P., Geetharathan, T., Sujatha, P., \& Deepika, G. (2012). Accumulation of lead and cadmium in the organs and tissues of albino rat. International journal of pharmacy \& life sciences., 3(12), 0976-7126.

Jurczuk, M., Brzóska, M. M., Moniuszko-Jakoniuk, J., Gałażyn-Sidorczuk, M., \& Kulikowska-Karpińska, E. (2004). Antioxidant enzymes activity and lipid peroxidation in liver and kidney of rats exposed to cadmium and ethanol. Food and Chemical Toxicology., 42(3), 429-438.

Kah, M., Levy, L., \& Brown, C. (2012). Potential for effects of land contamination on human. The case of cadmium. Journal of Toxicology and Environmental Health Part B, 15, 348-363.

Kaplan, O., Yildirim, N., Yildirim, N., \& Cimen, M. (2011). Toxic elements in animal products and environmental health. Asian Journal of Animal and Veterinary, 6, 228-232.

Katz, D. L., Doughty, K., \& Ali, A. (2011). Cocoa and chocolate in human health and disease. Antioxidants \& redox signaling., 00(00), 1-33.

Kostecka-Sochoń, P., \& Dąbrowska, E. (2013). Wpływ kadmu i/lub cynku na wybrane enzymatyczne parametry bariery antyoksydacyjnej w śliniance podjęzykowej szczura. Dental and Medical Problems., 50, 282-290.

Kostecka-Sochoń, P., Onopiuk, B. M., \& Dąbrowska, E. (2018). Protective effect of increased zinc supply against oxidative damage of sublingual gland in chronic exposure to cadmium: experimental study on rats. Oxidative Medicine and Cellular Longevity, 1-8.

Krichah, R., Ben, R. K., Hallegue, D., Tebourbi, O., Joulin, V., Couton, D., \& Sakly, M. (2003). Acute cadmium administration induces apoptosis in rat thymus and testicle, but not liver. Journal of environmental studies., 12(5), 589-594.

Li, L., Dong, F., Xu, D., Du, L., Yan, S., Hu, H., ... Liu, J. (2016). Short-term, low-dose cadmium exposure induces hyperpermeability in human renal glomerular endothelial cells. Journal of Applied Toxicology, 36, 257-265.

Lu, D., Williams, P. G., \& Wang, G. (2009). Metabolic engineering for the development and manufacturing of pharmaceuticals. In J. Tao, G. Lin, \& A. Liese (Eds.), Biocatalysis for the pharmaceutical industry discovery, development, and manufacturing, (pp. 247-271). Singapore: Wiley.

Manach, C., Scalbert, A., Morand, C., Remesy, C., \& Jimenez, L. (2004). Polyphenols: food sources and bioavailability. The American Journal of Clinical Nutrition. 79(5), 727-747.

Manly, S. P., Padmanabha, R., \& Lowe, S. E. (2002). Natural products or not? How to screen for natural products in the emerging HTS paradigm. Methods in Molecular Biology, 190, 153-168.

Maskarinec, G. (2009). Cancer protective properties of cocoa: A review of the epidemiologic evidence. Nutrition and Cancer., 61(5), 573-579.
Mates, M., Segura, J. A., Alonso, F. J., \& Marquez, J. (2010). Roles of dioxins and heavy metals in cancer and neurological diseases using ROS-mediated mechanisms. Free Radical Biology \& Medicine, 49, 1328-1341.

Matović, V., Buha, A., Bulat, Z., \& Dukić-Ćosić, D. (2011). Cadmium toxicity revisited: focus on oxidative stress induction and interactions with zinc and magnesium. Archives of Industrial Hygiene and Toxicology., 62(1), 65-76.

Medeiros, N. d.-S., Koslowsky, M. R., Farias, W. M., Funchal, C., \& Dani, C. (2015). Total phenolic content and antioxidant activity of different types of chocolate, milk, semisweet, dark, and soy, cerebral cortex, hippocampus, and cerebellum of wistar rats. Biochemistry Research International, 2015, 9. https:// doi.org/10.1155/2015/294659

Moitra, S., Brashier, B., \& Sahu, S. (2014). Occupational cadmium exposure associated oxidative stress and erythrocyte fragility among jewelry workers in India. American Journal of Industrial Medicine., 57, 1064-1072.

Nasiadek, M., Skrzypińska-Gawrysiak, M., Daragó, A., Zwierzyńska, E., \& Kilanowicz, A. (2014). Involvement of oxidative stress in the mechanism of cadmiuminduced toxicity on rat uterus. Environmental Toxicology and Pharmacology, 38, 364-373.

Navas-acien, A., Tellez-plaza, M., Guallar, E., Muntner, P., Silbergeld, E., Jaar, B., \& Weaver, V. (2009). Blood cadmium and lead and chronic kidney disease in US adults: a joint analysis. American Journal of Epidemiology, 170, 1156-1164.

Nehlig, A. (2013). The neuroprotective effects of cocoa flavanol and its influence on cognitive performance. British Journal of Clinical Pharmacology, 75(3), 716-727.

Nemmiche, S. (2017). Oxidative signaling response to cadmium exposure. Toxicological Sciences., 156(1), 4-10.

Neuwelt, E. A., Hamilton, B. E., Varallyay, C. G., et al. (2009). Ultrasmall superparamagnetic iron oxides (USPIOs): a future alternative magnetic resonance (MR) contrast agent for patients at risk for nephrogenic systemic fibrosis (NSF)? Kidney International, 75(5), 465-474 [PMC free article].

Oteiza, P. I. (2012). Zinc and the modulation of redox homeostasis. Free Radical Biology \& Medicine., 53(9), 1748-1759.

Paniagua-Castro, N., Escalona-Cardoso, G., Hernández-Navarro, D., Pérez-Pastén, R., \& Chamorro-Cevallos, G. (2011). Spirulina (Arthrospira) protects against cadmium-induced teratogenic damage in mice. Journal of Medicinal Food, 14(4), 398-404

Peters, J. L., Perlstein, T. S., Perry, M. J., Mcneely, E., \& Weuve, J. (2010). Cadmium exposure in association with history of stroke and heart failure. Environmental Research, 110, 199-206.

Powell, S. R. (2000). The antioxidant properties of zinc. Journal of Nutrition, 130(Suppl. 5S), 1447-1454.

Rahadian, D., Saputro, A. D., Rottiers, H., de Walle, D. V., \& Dewettinck, K. (2018). Physicochemical properties and antioxidant activities of chocolates enriched with engineered cinnamon nanoparticles. European Food Research and Technology., 244(7), 1185-1202.

Rahman, M., Ukiana, J., Uson-Lopez, R., Sikder, M. T., Saito, T., \& Kurasaki, M. (2017). Cytotoxic effects of cadmium and zinc co-exposure in PC12 cells and the underlying mechanism. Chemico-Biological Interactions., 269, 41-49.

Ramiro-Puig, E., \& Castell, M. (2009). Cocoa: antioxidant and immunomodulator. The British Journal of Nutrition, 101, 931-940.

Renugadevi, J., \& Prabu, S. M. (2010). Quercetin protects against oxidative stressrelated renal dysfunction by cadmium in rats. Experimental and Toxicologic Pathology, 62, 471-481.

Richter, M., \& Lannes, S. C. D. S. (2007). Ingredients used in chocolate industry. Revista Brasileira de Ciencias Farmaceuticas., 43(3), 357-369.

Rogalska, J., Piłat-Marcinkiewicz, B., \& Brzóska, M. M. (2011). Protective effect of zinc against cadmium hepatotoxicity depends on this bioelement intake and level of cadmium exposure: a study in a rat model. Chemico-Biological Interactions., 193(3), 191-203.

Sarwar, N., Malhi, S. S., Zia, M. H., Naeem, A., Bibi, S., et al. (2010). Role of mineral nutrition in minimizing cadmium accumulation by plants. Journal of the Science of Food and Agriculture, 90, 925-937.

Schwartz, G. G., Il'yasova, D., \& Ivanova, A. (2003). Urinary cadmium, impaired fasting glucose, and diabetes in the NHANES III. Diabetes Care, 26, 468-470.

Singh, P., Chaudhary, S., Patni, A., \& Sankhla, V. (2007). Effect of cadmium chloride induced genotoxicity in bone marrow chromosomes of Swiss albino mice and subsequent protective effects of Emblica officinalis and vitamin C. Journal of Herbal Medicine and Toxicology., 1(2), 67-71.

Siu, E. R., Mruk, D. D., Porto, C. S., \& Cheng, C. Y. (2009). Cadmiuminduced testicular injury. Toxicology and Applied Pharmacology, 238, 440-449.

Souza, P. F. Diamante, M. A. S., \& Dolder, H. (2010). Testis response to low doses of cadmium in Wistar rats. International Journal of Experimental Pathology, 91, 125-131. 
Spada, P. D. S., Souza, G. G. N., Dani, C., et al. (2009). Atividade antioxidante in vivo de frutas congeladas. Ci encia emMovimento., 21, 51-56.

Tongliang, B. U., Yuling, M. I., Weidong, Z., \& Caiqiao, Z. (2011). Protective effect of quercetin on cadmium-induced oxidative toxicity on germ cells in male mice. The anatomical record., 294, 520-526.

Tripathi, S., \& Srivastav, A. K. (2011). Cytoarchitectural alterations in kidney of Wistar rat after oral exposure to cadmium chloride. Tissue \& Cell, 43, 131-136.

Vasiljeva, S., Berzina, N., \& Remeza, I. (2011). Dietary modulation of immune responses by ascorbic acid in healthy and cadmium-induced immunocompromised chickens. Proceedings of the Latvian Academy of Sciences., 65(3/4), 110-116.

Vasiljeva, S., Smirnova, G., Basova, N., \& Babarykin, D. (2018). Cadmium-induced oxidative damage and protective action of fractioned red beet (Beta vulgaris) root juice in chickens. Agronomy Research, 16(S2), 1517-1526.

Vinson, J. A., Proch, J., Bose, P., Muchler, S., Taffera, P., Shuta, D., ... Agbo, G. (2006). Chocolate is a powerful ex vivo and in vivo antioxidant, an antiatherosclerotic agent in an animal model, and a significant contributor to antioxidants in the European and American diets. J Agric Food Chem, 54(21), 8071-6.

Waalkes, M. (2003). Cadmium carcinogenesis. Mutation Research, Fundamental and Molecular Mechanisms of Mutagenesis, 533, 107-120.

Warheit, D. B., Hoke, R. A., Finlay, C., Donner, E. M., Reed, K. L., \& Sayes, C. M. (2007). Development of a base set of toxicity tests using ultrafine $\mathrm{TIO} 2$ particles as a component of nanoparticles risk management. Toxicology Letters, 171, 99-110.

Watkins, R., Wu, L., Zhang, C., Davis, R. M., \& Xu, B. (2015). Natural product-based nanomedicine: recent advances and issues. International Journal of Nanomedicine, 10, 6055-6074.

Weisburger, J. H. (2001). Chemopreventive effects of cocoa polyphenols on chronic diseases. Experimental Biology and Medicine, 226(10), 891-897.

Wollgast, J., \& Anklam, E. (2000). Review on polyphenols in Theobroma cacao: changes in composition during the manufacture of chocolate and methodology for identification and quantification. Food Research International., 33(6), 423-447.

\section{Submit your manuscript to a SpringerOpen ${ }^{\circ}$ journal and benefit from:}

- Convenient online submission

- Rigorous peer review

- Open access: articles freely available online

- High visibility within the field

- Retaining the copyright to your article

Submit your next manuscript at $\boldsymbol{\nabla}$ springeropen.com 